
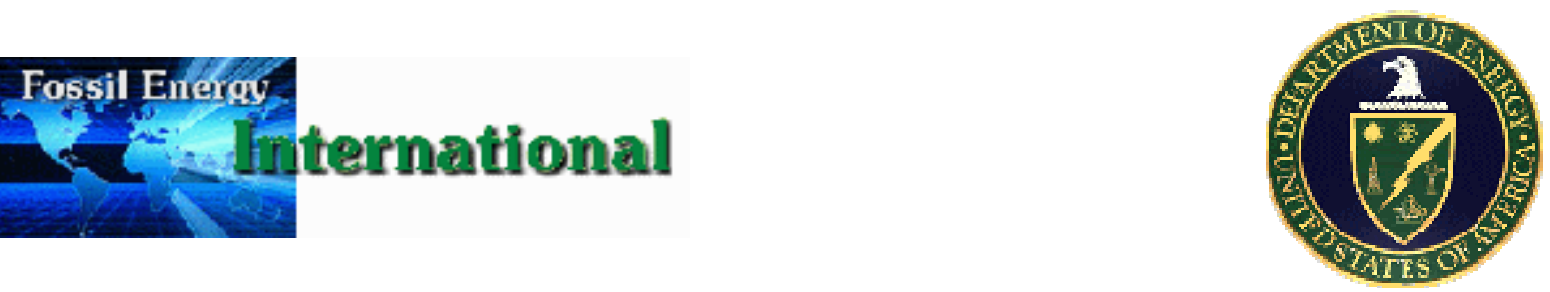

\title{
An Energy Overview of the Republic of Azerbaijan
}

\section{General Information}

The Republic of Azerbaijan is slightly smaller in area than Maine and has a population of about 7.8 million. Azerbaijan is one of the trans-Caucasus republics formed from the breakup of the Soviet Union; it is bordered by Russia and Georgia to the north, Armenia to the west, Iran to the south, and the Caspian Sea to the east. The Nakchivan Autonomous Republic, an enclave separated from the rest of Azerbaijan, is bordered by Turkey and Armenia to the north, Armenia to the east, and Iran to the west and south. There are 59 administrative regions (called 'rayonlar') in Azerbaijan; these are shown in Figure 1. The capital city, Baku (sometimes known as Baki), is a port on the Caspian Sea (in the eastern part of the country) and has a population of about 1.22 million. Azerbaijan's currency, the manat, has an exchange rate (as of August 2003) of about 4,910 manat per U.S. dollar. Azerbaijan's GDP (based on purchasing power parity) was $\$ 27$ billion in 2002, which ranks it 88th among 212 countries and territories. 
Figure 1: Administrative Regions of Azerbaijan

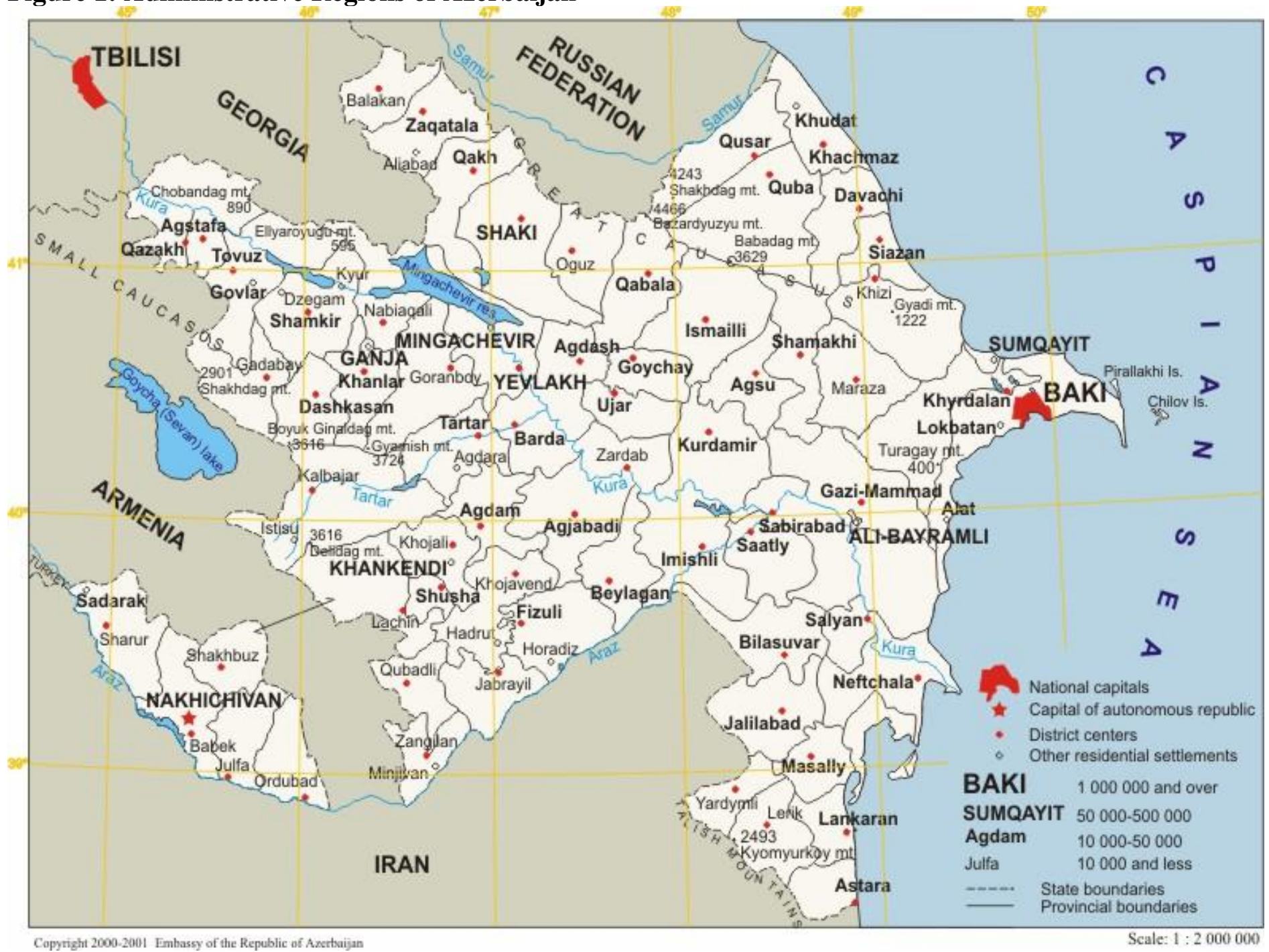

Source: Embassy of Azerbaijan

The largely Armenian enclave of Nagorno-Karabakh inside Azerbaijan was the subject of hostilities between Armenia and Azerbaijan in the early 1990s; a cease fire has been in effect since then with Armenia in control of the region, but there has not yet been a formal resolution. Azerbaijan has maintained a trade embargo against Armenia since the beginning of the war. In 2002, the Presidents of Azerbaijan and Armenia initiated a series of meetings in an attempt to find a long-term solution to the disputes between the two countries.

\section{Energy Policy and Regulation}

Azerbaijan's energy policy seems mostly centered on facilitating the development and export of its huge hydrocarbon reserves. In April 2001, Azerbaijan established its Fuel and Energy 
Ministry; this new entity's main function is to boost foreign investment in Azerbaijan's energy sector. The new Ministry will also supervise the state-owned oil and gas companies and set import tariffs in those sectors.

During the last half of the 1990s and the beginning of this decade, several laws were enacted in a so far mostly unsuccessful attempt to bring the energy sector into market-based operation. These included a law on usage of energy resources (enacted in 1996), a law on electric power generation (enacted in 1998), and a law specifically covering thermal-electric power plants (enacted in 2000). There have also been several Decrees, by both the President of Azerbaijan and the Cabinet of Ministers, concerning regulation of the energy sector, including one in December 2001 that listed nine very small hydroelectric power plants that were available for privatization.

On March 25, 2002, the President of Azerbaijan issued Decree \#893, "On Strengthening of Financial Discipline in the Energy Sector." The decree was issued because Azerenergy (the stateowned joint stock electric company) and Azerigas (the state-owned joint stock gas company) have only paid for a small percentage of their fuel deliveries and have continued to increase their debts to the State Oil Company of the Azerbaijani Republic (SOCAR). In 2001, Azerenergy paid SOCAR for only $0.5 \%$ of the value of its fuel while Azerigas paid for just $1.3 \%$ of the value of its gas. The decree lays out a two-stage approach to the problem. Stage 1 implements measures to prevent creating new debts. Payments to SOCAR are planned at $20 \%$ in $2002,30 \%$ in 2003 , $45 \%$ in 2004, 65\% in 2005, and $80 \%$ to $100 \%$ in 2006. During Stage 1, the unpaid amounts will be regulated through securities to provide record-keeping and transparency. In Stage 2, the debt will be restructured when the accrual of new debts has been stopped. By the end of 2006, Azerbaijan plans to increase collection from distribution networks to $100 \%$.

Decree \#893 also sets a goal of eventually switching all thermal power plants to natural gas fuel and announces plans to restructure Azerenergy and Azerigas and speed up the process of privatization or concession of electricity and gas distribution networks. The decree states that a Tariff Board has been established that will do a comprehensive analysis of utility tariffs, set optimum levels, and promptly regulate them. In addition, Decree \#893 announces the government's intention to restructure SOCAR. This would include improving the settlement operations of SOCAR with its industrial customers and increasing collections from domestic fuel users. Azerbaijan intends to reduce costs by privatizing SOCAR's servicing and social facilities or transferring them to other institutions. It is planned that the differential between domestic and export prices will be reduced for oil, oil products, and natural gas.

The Azeri government recognizes that to create free competitiveness in the power generation subsector, several measures must be fully implemented: fair tariffs and non-discriminatory access to the high voltage power grid, creation of true independent power generation companies, implementation of a power trading and resale system, and re-thinking the taxation system for power generation in order to discourage monopolistic control of the power market and encourage alternate forms of power generation. Future laws and decrees toward this end can therefore be expected. 


\section{Energy Summary}

Azerbaijan is a major oil producer and could also be a major natural gas producer if there was sufficient gas transmission infrastructure in place that could move the gas to western markets. Azerbaijan has encouraged foreign investment in its oil and gas subsectors since it became an independent country in the early 1990s.

Development of its hydrocarbon resources has allowed Azerbaijan to transition from being a net energy importer to a net energy exporter. An historical summary of Azerbaijan's Total Primary Energy Production (TPEP) and Consumption (TPEC) is shown in Table 1.

Table 1: Azerbaijan's TPEP and TPEC, 1992-2001 (in Quads)

\begin{tabular}{|l|l|l|l|l|l|l|l|l|l|l|}
\hline & 1992 & 1993 & $\mathbf{1 9 9 4}$ & $\mathbf{1 9 9 5}$ & $\mathbf{1 9 9 6}$ & $\mathbf{1 9 9 7}$ & $\mathbf{1 9 9 8}$ & $\mathbf{1 9 9 9}$ & $\mathbf{2 0 0 0}$ & $\mathbf{2 0 0 1}$ \\
\hline TPEP & 0.78 & 0.72 & 0.66 & 0.65 & 0.65 & 0.62 & 0.73 & 0.84 & 0.84 & 0.89 \\
\hline TPEC & 0.99 & 0.85 & 0.76 & 0.73 & 0.65 & 0.64 & 0.55 & 0.57 & 0.53 & 0.57 \\
\hline
\end{tabular}

note: 1 Quad = 1 quadrillion Btu

Source: DOE/EIA

\section{Oil}

\section{Exploration and Reserves}

Azerbaijan was the world's first oil producing country, and has the potential of becoming one of the most important. Azerbaijan presently has in the range of 4-13 billion barrels of proven oil reserves (depending on the source consulted), and there are also most likely very large additional reserves offshore in the Caspian Sea.

In 1994, 10 energy companies signed a 30-year $\$ 8$ billion contract with Azerbaijan in what is being referred to as "the deal of the century." This resulted in formation of the Azerbaijan International Operating Company (AIOC), which began operations under Azerbaijan's first production sharing agreement (PSA) in 1997 under the leadership of BP of the United Kingdom. AIOC has an $\$ 8$ billion 30-year contract to develop three fields -- Azeri, Chirag, and the deepwater portions of Gunashli (ACG). The total estimated reserves of ACG are 4.3 billion barrels of oil.

There are now 33 major oil companies active in Azerbaijan, including ones from the United States, the United Kingdom, Russia, Saudi Arabia, and Japan. Azerbaijan has since signed 21 major oil field agreements (including both joint ventures and PSAs) with those 33 companies, resulting in more than $\$ 4$ billion investment in Azerbaijan's oil subsector. However, joint ventures had limitations on exporting oil directly which discouraged development of some fields, so in 2000, Azerbaijan decided to abolish joint ventures and convert them to PSAs. Recent exploratory drilling has produced mixed results and several PSAs shut down after they were unsuccessful in finding oil. 
The status of some offshore Caspian oil fields is still being disputed. Azerbaijan, Kazakhstan, and Russia have generally agreed among themselves to divide the offshore area on the basis of equidistant division of the sea. However, Iran and Turkmenistan have argued for different ways. Azerbaijan has disputes with Turkmenistan over the Kyapaz-Serdar, Khazar, and Osman fields. Azerbaijan also disputes Iran's claims in awarding licenses to Royal Dutch Shell and Lasmo to do seismic exploration in the Caspian offshore area near the two countries. In July 2001, an Iranian gunboat ordered a BP ship to leave the South Caspian area where it was exploring its Araz, Alov, and Sharg concession under a license from Azerbaijan.

\section{Production and Consumption}

Azerbaijan's oil industry is run by SOCAR, which operates 40 of the older oil fields, many of which have been producing for more than 50 years and have had steadily declining production rates. These older depleted fields have been stimulated for many years with water flooding, and as a result there is a high water content in their product.

More than $80 \%$ of the oil production of Azerbaijan is now from offshore fields in the Caspian, especially the Gunashli field 60 miles off the coast. AIOC has also produced considerable oil from the Chirag-1 stationary platform. In August 2001, the government of Azerbaijan and AIOC signed an agreement to expand ACG by investing \$3.3 billion. This expansion plan is designated "Phase One," and includes a drilling platform for 48 wells, a natural gas compressing facility, an underwater pipeline from the field, and a modernization of the oil terminal. AIOC's production is now about 130,000 barrels per day (b/d). It is projected that, with these improvements, ACG could produce 400,000 b/d by 2005 .

Overall, crude oil production has been increasing since the late 1990s because of foreign investment and new technologies. An historical summary of petroleum production and consumption in Azerbaijan is shown in Table 2.

Table 2: Petroleum Production and Consumption in Azerbaijan, 1992-2001 (in thousands of $b / d$ )

\begin{tabular}{|l|l|l|l|l|l|l|l|l|l|l|l|l|}
\hline & 1992 & 1993 & 1994 & 1995 & 1996 & 1997 & 1998 & 1999 & 2000 & 2001 \\
\hline Production (total)* & 222 & 208 & 192 & 182 & 182 & 180 & 237 & 283 & 286 & 307 \\
\hline Production (Crude Oil only) & 213 & 200 & 184 & 175 & 176 & 173 & 230 & 276 & 280 & 301 \\
\hline Consumption & 203 & 194 & 187 & 179 & 134 & 129 & 146 & 149 & 137 & 140 \\
\hline
\end{tabular}

* includes crude oil, natural gas plant liquids, other liquids, and refinery processing gain Source: DOE/EIA

\section{Refineries and Downstream Processing}

Azerbaijan has two petroleum refineries, both located in Baku. The Novobakinsky Refinery (NBR), with a capacity of 212,000 b/d, emphasizes production of gasoline, while the Azerneftiag refinery, with a capacity of 230,000 b/d, produces fuels and lubricating oils. An historical 
summary of Azerbaijan's cumulative refined petroleum products output by fuel type from its two refineries is shown in Table 3.

Table 3: Output of Refined Petroleum Products in Azerbaijan, 1992-2000 (in thousands of $\mathbf{b} / \mathbf{d}$ )

\begin{tabular}{|l|r|r|r|r|r|r|r|r|r|r|r|}
\hline \multirow{2}{*}{ Refined Product } & \multicolumn{7}{|c|}{ Production Rate } \\
\cline { 2 - 5 } & $\mathbf{1 9 9 2}$ & $\mathbf{1 9 9 3}$ & $\mathbf{1 9 9 4}$ & $\mathbf{1 9 9 5}$ & $\mathbf{1 9 9 6}$ & $\mathbf{1 9 9 7}$ & $\mathbf{1 9 9 8}$ & $\mathbf{1 9 9 9}$ & $\mathbf{2 0 0 0}$ \\
\hline Motor Gasoline & 23 & 26 & 28 & 21 & 17 & 19 & 22 & 23 & 20 \\
\hline Jet Fuel & 9 & 17 & 9 & 11 & 11 & 13 & 15 & 14 & 13 \\
\hline Kerosene & 25 & 11 & 12 & 12 & 10 & 3 & 4 & 11 & 4 \\
\hline Distillate Fuel Oil & 86 & 45 & 47 & 80 & 43 & 44 & 48 & 62 & 68 \\
\hline Residual Fuel Oil & 61 & 84 & 78 & 81 & 75 & 73 & 76 & 73 & 48 \\
\hline Liquefied Petroleum Gases & 13 & 10 & 16 & 10 & 13 & 6 & 2 & 5 & 2 \\
\hline Lubricants & 17 & 10 & 4 & 4 & 2 & 2 & 2 & 0 & 0 \\
\hline Other * & 21 & 21 & 23 & 7 & 11 & 5 & 9 & 11 & 25 \\
\hline Total & $\mathbf{2 5 6}$ & $\mathbf{2 2 5}$ & $\mathbf{2 1 7}$ & $\mathbf{2 2 5}$ & $\mathbf{1 8 3}$ & $\mathbf{1 6 5}$ & $\mathbf{1 7 7}$ & $\mathbf{1 9 9}$ & $\mathbf{1 7 9}$ \\
\hline Refinery Fuel and Loss & 10 & 9 & 8 & 9 & 7 & 6 & 7 & 8 & 7 \\
\hline
\end{tabular}

* includes asphalt, coke, napthas, paraffin wax, and petrochemical feedstocks note: components may not add to total due to rounding Source: DOE/EIA

There has been a downward trend for production rate over the past decade, and the combined overall production rate is now only about $40 \%$ of the nameplate combined capacity of the two refineries. Part of this decline is due to Azerbaijan's reduced consumption of petroleum over that time period, but the refineries have also been neglected, in terms of capital expenditures for maintenance and upgrading. The Azeri government has estimated that the combined cost for much-needed refurbishments for the refineries would cost between $\$ 600$ million and $\$ 700$ million. In January 2002, the U.S. Trade and Development Agency selected ABB Lummus as the winner of the tender to do a feasibility study for these improvements; the study is expected to also include improvements to the specialized oil port of Dubendi. The modernization of the refineries and the Dubendi project will help Azerbaijan to utilize the Baku-Ceyhan pipeline now under construction, as it is planned that the refineries will process lower quality imported crude while higher quality crude produced in Azerbaijan will go into the pipeline.

Historically, about one-quarter of Azerbaijan's refined petroleum products are exported, the majority of which is distillate fuel oil. An historical summary of Azerbaijan's exports and imports of selected petroleum products is shown in Table 4. 
Table 4: Azerbaijan's Exports and Imports of Refined Petroleum Products, 1992-2000 (in thousands of $\mathbf{b} / \mathbf{d}$ )

\begin{tabular}{|c|c|c|c|c|c|c|c|c|c|c|}
\hline Fuel Type & & 1992 & 1993 & 1994 & 1995 & 1996 & 1997 & 1998 & 1999 & 2000 \\
\hline Motor Cacolino & Exports & 2 & 3 & 2 & 7 & 7 & 7 & 8 & 4 & 2 \\
\hline Ivotor Gasome & Imports & $\underline{0}$ & 0 & 0 & 0 & 0 & 0 & $\underline{0}$ & 0 & 0 \\
\hline Jot Fuol & Exports & 3 & 0 & 0 & 0 & 0 & 0 & 0 & 0 & 10 \\
\hline Jet ruel & Imports & 0 & 0 & 0 & 0 & 0 & 0 & 0 & 0 & 0 \\
\hline & Exports & 0 & 4 & 3 & 2 & 0 & 0 & 1 & 8 & 0 \\
\hline Kerosene & Imports & 0 & $\underline{0}$ & 0 & 0 & 0 & 0 & $\underline{0}$ & 0 & 0 \\
\hline Distillate & Exports & 37 & 20 & 23 & 22 & 37 & 33 & 32 & 33 & 25 \\
\hline Fuel Oil & Imports & $\underline{0}$ & 0 & 0 & 0 & $\underline{0}$ & 1 & 1 & $\underline{0}$ & $\underline{0}$ \\
\hline Residual & Exports & 6 & 0 & 1 & 16 & 2 & 0 & 6 & $\underline{0}$ & 5 \\
\hline Fuel Oil & Imports & $\underline{0}$ & 0 & 0 & 1 & 1 & 0 & 0 & $\overline{4}$ & 1 \\
\hline Liquefied & Exports & 0 & 0 & 0 & 0 & 0 & 0 & $\underline{0}$ & 0 & 0 \\
\hline Petroleum Gases & Imports & 0 & 0 & 0 & 0 & 0 & 0 & $\underline{0}$ & 0 & 1 \\
\hline I ubricantc & Exports & 0 & 3 & 2 & 2 & $\underline{0}$ & 2 & 1 & 0 & 0 \\
\hline UDricants & Imports & 0 & $\underline{0}$ & $\underline{0}$ & $\underline{0}$ & $\underline{0}$ & $\underline{0}$ & $\underline{0}$ & 0 & 0 \\
\hline Other* & Exports & 13 & 1 & $\underline{0}$ & $\underline{0}$ & 5 & 3 & 1 & 0 & 1 \\
\hline Other* & Imports & $\underline{0}$ & $\underline{0}$ & $\underline{\overline{0}}$ & $\overline{0}$ & $\underline{0}$ & 0 & 0 & 0 & $\underline{0}$ \\
\hline & Exports & 57 & 31 & 31 & 50 & 51 & 46 & 49 & 48 & 44 \\
\hline Total & Imports & 1 & $\underline{\mathbf{0}}$ & $\underline{\mathbf{0}}$ & 1 & 2 & 1 & 2 & 5 & 2 \\
\hline
\end{tabular}

* includes asphalt, coke, naphthas, paraffin wax, and petrochemical feedstocks note: quantity of "0" (underlined) actually means "less than $500 \mathrm{~b} / \mathrm{d}$ " components may not add to total due to rounding

Source: DOE/EIA

\section{Natural Gas}

Exploration and Reserves

Azerbaijan has in the range of 11-30 trillion cubic feet (Tcf) of proven natural gas reserves (depending on the source consulted). However, there is insufficient infrastructure to move associated gas from many of the Caspian offshore oil fields and some of it is being flared. In 1999, Azerbaijan passed a law requiring planning for associated gas exploitation to go with each oil project. In October 1999, SOCAR and TDA signed a \$425,000 agreement to help fund a comprehensive natural gas study.

The Shah Deniz natural gas field, which was discovered in 1999, is estimated to contain between 25 Tcf and 39 Tcf, making it the largest find of the last 20 years. The estimated cost for development and infrastructure at Shah Deniz is $\$ 4.5$ billion and the first production is expected by 2006. The annual production rate is expected to be 286 billion cubic feet (Bcf). 
Of the other natural gas fields in Azerbaijan, the Nachivan field is estimated to contain 900 Bcf in reserves. There is also a natural gas reserve at Gunashli.

\section{Production and Consumption}

Over 95\% of Azerbaijan's gas production comes from offshore fields, rather than onshore. The Bakhar natural gas field currently accounts for more than $40 \%$ of Azerbaijan's natural gas production but the production of that field is declining because of a lack of new drilling. It is expected that increased future production will come from the Nachchivan, Gunashli, and Shah Deniz fields. Currently, SOCAR produces about 85\% of Azerbaijan's natural gas, and AIOC produces a small amount of associated gas (i.e., natural gas found with crude oil deposits).

Currently, Azerbaijan is a net importer of natural gas. In 2001, Azerbaijan imported 125 Bcf of Russian natural gas, of which 109 Bcf was supplied by Itera and the rest was from TransNafta. The 2002 imports from Russia are estimated to be 141 Bcf. SOCAR has an exclusive contract with Itera to purchase gas supplied through the Shirvanovka-Gadzhigabul pipeline at \$52 per 1,000 cubic meters.

It is expected that Azerbaijan will become a net exporter of natural gas in the future as the Shah Deniz field is developed. Azerbaijan has signed agreements with Statoil and BP to develop and export natural gas. Azerbaijan could have an annual natural gas production of 400-500 Bcf by 2010, once the infrastructure is in place and flaring of associated gas is eliminated.

Azerbaijan signed an agreement with Turkey in March 2001, under which it would begin deliveries of natural gas in 2004. However, project delays caused Azerbaijan and Turkey to renegotiated their agreement in February 2003, and now gas exports to Turkey will begin in 2006. The new schedule calls for 71 billion cubic feet (Bcf) to be delivered in 2006, increasing to 222 Bcf in 2009. The gas going to Turkey will most likely come from the Shah Deniz field, as it is developed, with SOCAR supplying the gas produced by the international consortium developing the field.

An historical summary of natural gas production and consumption in Azerbaijan is shown in Table 5.

Table 5: Dry Natural Gas Production and Consumption in Azerbaijan, 1992-2001 (in Tcf)

\begin{tabular}{|l|l|l|l|l|l|l|l|l|l|l|}
\hline & 1992 & 1993 & 1994 & 1995 & 1996 & 1997 & 1998 & 1999 & 2000 & 2001 \\
\hline Production & 0.275 & 0.240 & 0.225 & 0.232 & 0.237 & 0.210 & 0.197 & 0.212 & 0.200 & 0.202 \\
\hline Consumption & 0.523 & 0.388 & 0.332 & 0.318 & 0.328 & 0.323 & 0.197 & 0.212 & 0.200 & 0.237 \\
\hline
\end{tabular}

note: "dry" gas means gas with condensates removed Source: DOE/EIA 


\section{Coal}

Azerbaijan has no significant deposits of coal, and currently no coal production. Azerbaijan's coal consumption has decreased since the early 1990s, as its use has been displaced by other fuels. An historical summary of coal production and consumption in Azerbaijan is shown in Table 6.

Table 6: Coal Production and Consumption in Azerbaijan, 1992-2001 (in millions of short tons)

\begin{tabular}{|l|c|c|c|c|c|c|c|c|c|c|c|c|}
\hline \multicolumn{1}{|c|}{} & 1992 & 1993 & 1994 & 1995 & 1996 & 1997 & 1998 & 1999 & 2000 & 2001 \\
\hline Production & n/a & n/a & n/a & n/a & n/a & n/a & n/a & n/a & n/a & n/a \\
Anthracite & $n / a$ & $n / a$ & $n / a$ & $n / a$ & $n / a$ & $n / a$ & $n / a$ & $n / a$ & $n / a$ & $n / a$ \\
Bituminous & $n / a$ & $n / a$ & $n / a$ & $n / a$ & $n / a$ & $n / a$ & $n / a$ & $n / a$ & $n / a$ & $n / a$ \\
Lignite & $n / a$ & $n / a$ & $n / a$ & $n / a$ & $n / a$ & $n / a$ & $n / a$ & $n / a$ & $n / a$ & $n / a$ \\
\hline Consumption & 0.16 & 0.00 & 0.04 & 0.00 & 0.01 & 0.01 & 0.01 & 0.00 & 0.00 & 0.00 \\
\hline
\end{tabular}

n/a - not applicable

Source: DOE/EIA

\section{Hydroelectric and Other Renewable Energy}

Hydroelectric Power

Azerbaijan's longest and most important river is the Kura, which flows southeastward through the middle of the country and empties into the Caspian Sea. The Kura watershed, which includes its major tributary, the Araz (sometimes known as the Aras, the Araks, or the Arax; many of Azerbaijan's other rivers also have variants in their spelled names), encompasses more than $80 \%$ of Azerbaijan. Azerbaijan also has an extensive network of canals and water pipelines, totalling more than 40,000 kilometers in length, for irrigation purposes. A map of Azerbaijan's major rivers and canals is shown in Figure 2. 
Figure 2: Azerbaijan's Rivers and Canals

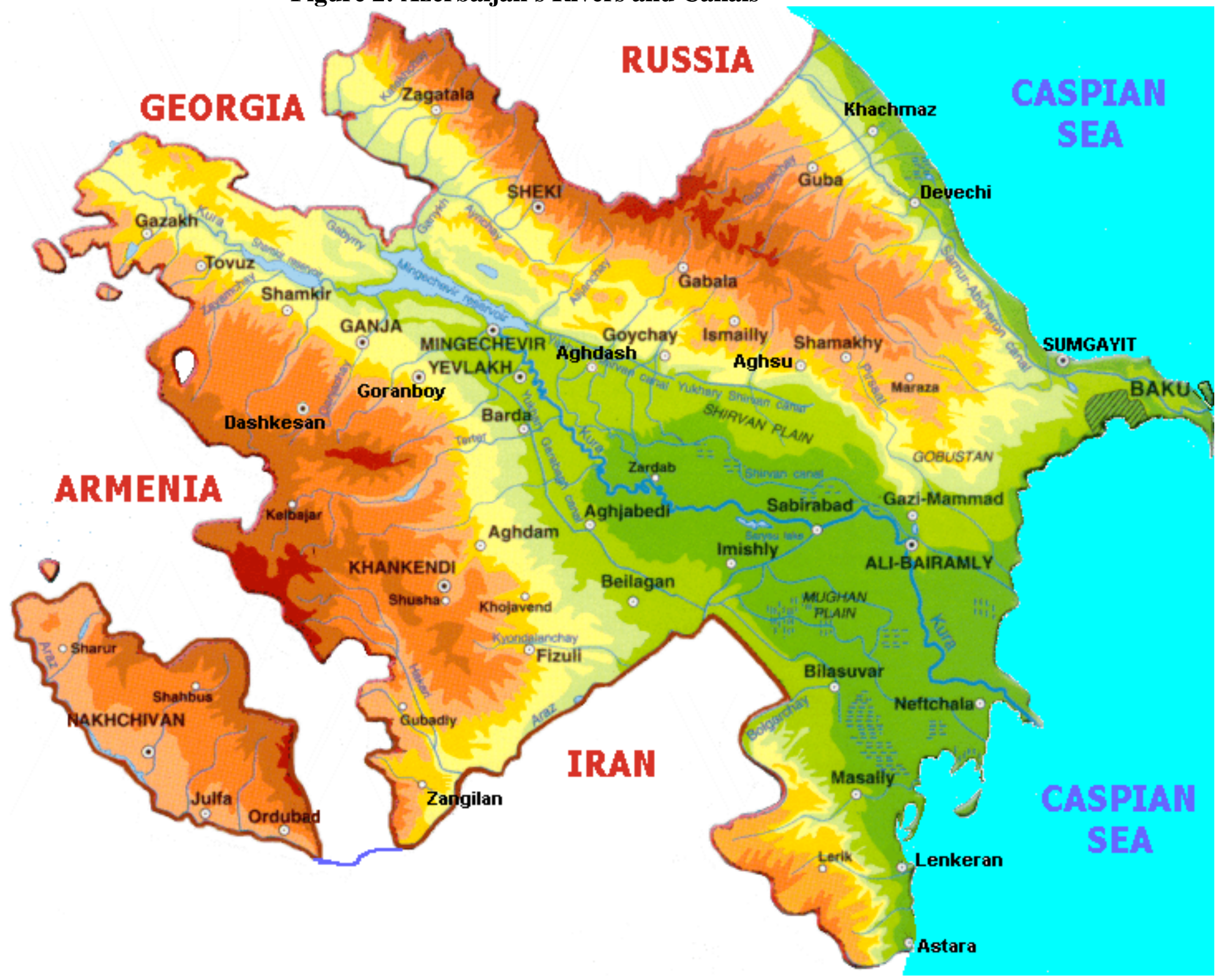

Source: AzerWeb

The largest hydroelectric power plant is the 402 megawatt (MWe) Mingachevir facility on the Kura River. There are presently three hydroelectric power plants of more than $100 \mathrm{MWe}$ capacity in Azerbaijan, all of which are on the Kura.

The six-unit Mingechevir power plant, located on the Kura River 250 kilometers west of Baku, has had reconstruction work recently completed that resulted in a capacity increase from 360 MWe to 402 MWe. The three-unit Yenikend power plant, also on the Kura, was completed in May 2000, but there are plans to add an additional unit that will bring its total capacity up to 150 MWe. 
The Araz hydropower plant, located on the Araz River on the border with Iran, was built in cooperation with Iran with each country having a two-unit 22 MWe hydropower plant designated for its own use. The Araz facility serves Azerbaijan's Nakchivan enclave and is not connected to the Azeri main power grid. The two-unit Tartar hydropower plant (also known as the Serseng power plant) is located on the Tartar River in an area now controlled by Armenia.

\section{Other Renewable Energy}

The Strategic Development Department of Azerbaijan's Ministry of Fuel and Energy has expressed interest in utilization of alternative and renewable sources of energy. The Ministry is working on this issue with donor organizations such as the Norwegian Association of Certified Engineers, which is assisting the Ministry in establishing a center to support energy efficiency, environmental protection, and clean energy production initiatives.

\section{Energy Transmission Infrastructure}

Electricity Transmission and Distribution

The state-owned company Azerenergy SC owns all of the high voltage transmission lines in Azerbaijan and also controls dispatch of the high voltage grid. The transmission grid voltages are 500 kilovolts $(\mathrm{kV}), 330 \mathrm{kV}, 220 \mathrm{kV}$, and $110 \mathrm{kV}$. A breakdown of the components in the Azerenergy high voltage grid is shown in Table 7.

\section{Table 7: Azerbaijan's High Voltage Electricity Grid}

\begin{tabular}{|c|c|}
\hline $\begin{array}{c}\text { Voltage } \\
\text { (kV) }\end{array}$ & $\begin{array}{c}\text { Total Length } \\
\text { (kilometers) }\end{array}$ \\
\hline 500 & 694 \\
\hline 330 & 961 \\
\hline 220 & 1,226 \\
\hline 110 & 2,283 \\
\hline
\end{tabular}

Source: Shems Energy Ltd. for World Bank

Power distribution within Azerbaijan is handled by four regional joint stock companies, Bakuelectricshebeke SC, Ali Bayramlyelectricshebeke SC, Gandjaelectricshebeke SC, and Sumgayitelectricshebeke SC, each of which purchases electricity wholesale from Azerenergy for resale. Each of these four regional companies has a distribution monopoly in its territory (the autonomous region of Nakchivan also has its own separate electricity distribution network). Azerbaijan has transferred the management of these four regional distributors via long-term concession agreements to private investors, with the Baku and Sumgayit distribution networks now operated by Barmek, a Turkish firm, and the Ganja and Ali Bayramli distribution networks now operated by Factory Electric Facilities Production, an Azeri firm. Expected outside investment resulting from these transfers will enable much-needed modernization and upgrades to the networks, but the the regionals still face a financial challenge because of continuing problems with customers not paying their bills. A map of Azerbaijan's electricity grid, showing the coverage of the four regional companies, is shown in Figure 3. 




Source: Shems Energy Ltd. for World Bank

Azerbaijan's grid connections with other countries include $500 \mathrm{kV}, 330 \mathrm{kV}, 35 \mathrm{kV}$, and $10 \mathrm{kV}$ connections with Georgia; $154 \mathrm{kV}$ and $34.5 \mathrm{kV}$ connections with Turkey; and $230 \mathrm{kV}, 132 \mathrm{kV}$, and $10.5 \mathrm{kV}$ connections with Iran. Azerbaijan is part of the Trans-Caucasian Power Pool. However, some of Azerbaijan's equipment designated for the power pool is no longer functioning ever since the conflict with Armenia. In particular, all grid interconnects between Azerbaijan and Armenia have been shut down or were damaged during the hostilities.

\section{Oil Pipelines}

Azerbaijan's importance as a source of petroleum has benefited from the existence of two major transit pipelines. More yet are in planning and construction phases. A map of the major oil pipelines in Azerbaijan is shown in Figure 4. 


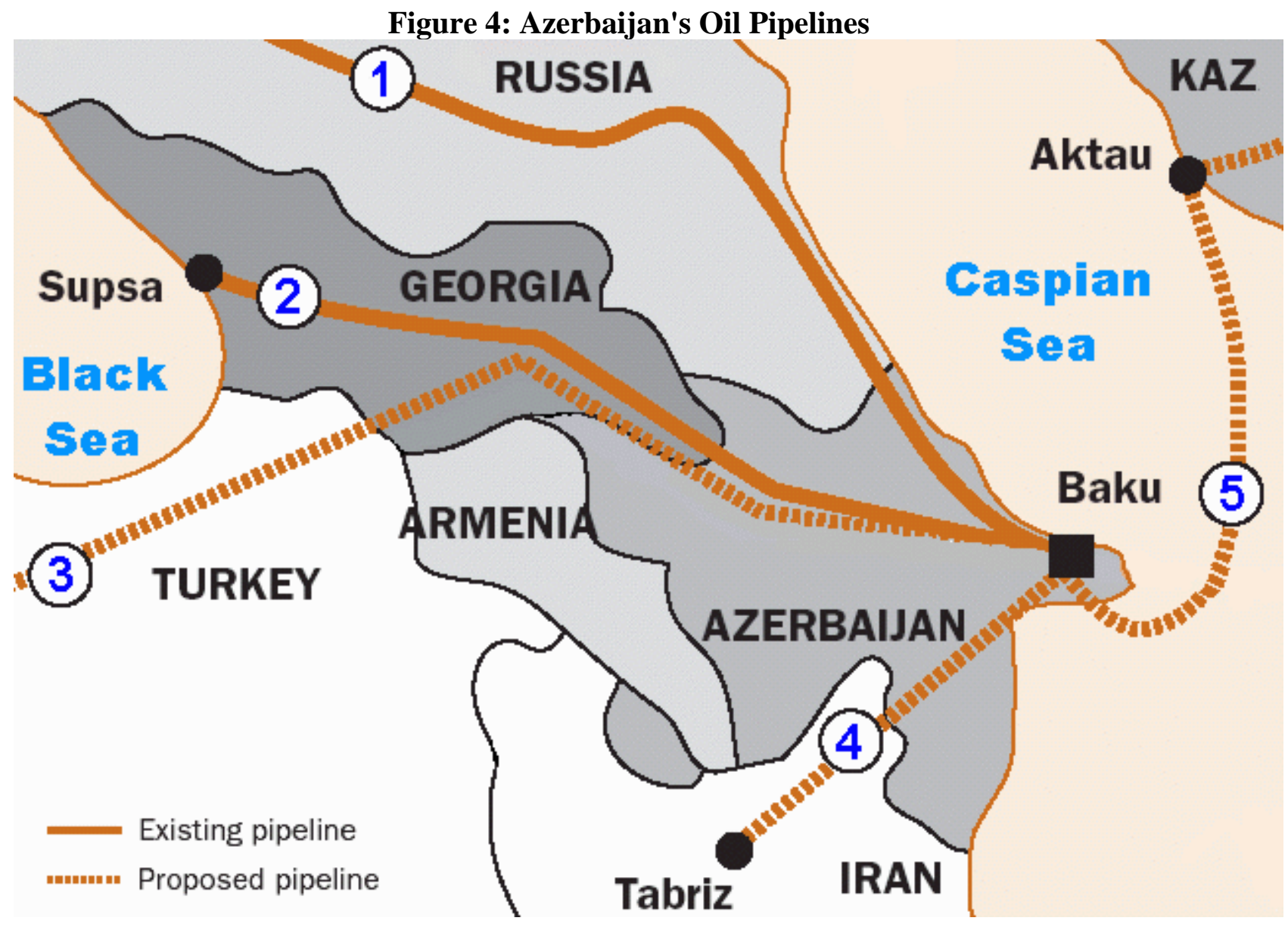

Key: 1 - Northern Pipeline; 2 - Western Pipeline; 3 - BTC Pipeline; 4 - Baku-Iran Pipeline; 5 - Trans-Caspian Pipeline Source: EBRD

The Northern Pipeline (\#1 in Figure 4) connects Baku to Novorossiysk in Russia and has a capacity of 103,000 b/d of crude oil, but there have been periods when it could not be used, since it passes through the area of conflict in Chechnya. Russian pipeline operator Transneft built a 120,000 b/d Chechnya pipeline bypass and restarted operation in December 2000. However, the Northern Pipeline has an oil quality problem, as Russia transports low quality heavy crude through the pipeline which gets mixed with the Azeri high quality light crude and thus reduces its value. SOCAR estimates that it lost \$40-\$50 million in oil revenue in 2001 because of the pipeline quality problem, and has suggested that an "oil quality bank" be set up for the other shippers to compensate it for the quality differential. Currently, SOCAR transports 50,000 b/d via the Northern Pipeline. AIOC has chosen to transport all its oil via the Western Pipeline instead, because of the higher expense and quality problems of the Northern Pipeline.

The Western Pipeline (\#2 in Figure 4) connects Baku to the Georgian port of Supsa on the Black Sea; it is capable of carrying 145,000 b/d and it is currently operating near full capacity. The Georgian International Oil Company, a subsidiary of AIOC, has built a \$550 million oil terminal in Supsa and upgraded the 515-mile pipeline. In 2001, AIOC exported 130,000 b/d of Azeri oil 
via this pipeline. Georgian officials have suggested increasing the pipeline capacity to $300,000 \mathrm{~b} / \mathrm{d}$ to accommodate the expected increases in AIOC's oil volume, but AIOC plans to use the new Baku-Tbilisi-Çeyhan Pipeline once it is finally completed.

In September 2002, there was a groundbreaking ceremony for the \$3 billion 1,730-kilometer Baku-Tbilisi-Çeyhan (BTC) Pipeline (\#3 in Figure 4). This pipeline, sometimes referred to as the Main Export Pipeline, will link Baku with the Turkish port of Çeyhan on the Mediterranean Sea via Tbilisi, Georgia and will transport about 1 million b/d of Azeri oil to the west. In addition, it could also someday carry Kazakh oil westward, if the proposed Trans-Caspian Pipeline (\#5 in Figure 4) is built. Current plans call for the BTC Pipeline to begin transporting oil in early 2005. Investors in the BTC Pipeline include most of the companies who had also invested in AIOC, and it is expected that these BTC investors will pay for $30 \%$ of the cost of the pipeline as their equity in the project with the remaining $70 \%$ to be financed by the U.S. ExIm Bank, Japan's ExIm Bank, the International Finance Corporation, and the EBRD.

Before the BTC Pipeline gathered general support, a 190-mile pipeline from Baku to Tabriz in northwest Iran had been proposed (\#4 in Figure 4), which would then connect with the existing Iranian pipeline network and feed Iranian refineries. Although advocates of this 200,000 to $400,000 \mathrm{~b} / \mathrm{d}$ pipeline had claimed it would be cheaper and easier to build than the BTC Pipeline and an international developer (France's TotalFinaElf) had expressed an interest, it is unlikely to be built. Azerbaijan has insisted that Iran first acquiesce on disputed Caspian offshore drilling rights before the matter can even be discussed but Iran has shown no willingness to do this. Also, the United States is opposed to any pipeline deals involving Iran. As a result, the Iran pipeline proposal is unlikely to find funding sources such as those who have come onboard for constructing the BTC Pipeline.

One other pipeline proposal that deserves mention is a proposed Ukranian pipeline that could transport Azeri oil to western Europe via Poland. Ukraine has recently built an oil terminal on the Black Sea coast at Pivdenny and in autumn of 2001, Ukraine (using its own funds) finished building the Odessa-Brody Pipeline. There still needs to be a connecting pipeline link from Brody to Plock (in Poland), however; once that is in place, Azeri oil could be transported westward via the southern Druzbha pipeline or northward to Poland. However, Azerbaijan is expressing little immediate interest in the proposal, and Ukraine has not yet found any customers for the Odessa-Brody Pipeline.

\section{Natural Gas Transmission and Storage}

During the Soviet era, an extensive natural gas infrastructure was built in Azerbaijan; this gas transmission and distribution network extends to over $80 \%$ of the population. There are presently 4,500 kilometers of high pressure transmission lines, 31,000 kilometers of medium and low pressure distribution lines, and seven compressor stations. This network now needs considerable modernization and rehabilitation -- because of corrosion, as much as $5 \%$ of the gas is being lost to leakage. The total losses of the system are currently 15\%, including gas not being billed to customers. The World Bank has financed the rehabilitation of the gas regulating and metering stations in the Absheron Peninsula around Baku. New meters with electronic flow calculators were installed in 52 of these stations. 
There are several major gas transmission pipelines within Azerbaijan. The most important are the 378-kilometer Gazi-Mammad-Gazakh twin pipelines that carry natural gas westward across Azerbaijan to the city of Gazakh near the Georgia border and 520-kilometer north-south AstaraShirvanovka pipeline that carries gas from the Iranian border to the Russian border.

Azerbaijan has two underground gas storage facilities, located southwest of Baku at Garadag and Galmaz. Both are derived from depleted gas wells and both are in need of upgrades to increase their storage capacities. Garadag has a current capacity of about 1 billion cubic meters, but it could hold about 5 billion cubic meters if upgraded. Galmaz also has a current capacity of about 1 billion cubic meters, but it could be upgraded to about 2.5 billion cubic meters capacity.

A map of Azerbaijan's natural gas transmission network is shown in Figure 5.

Figure 5: Azerbaijan's Natural Gas Transmission Network

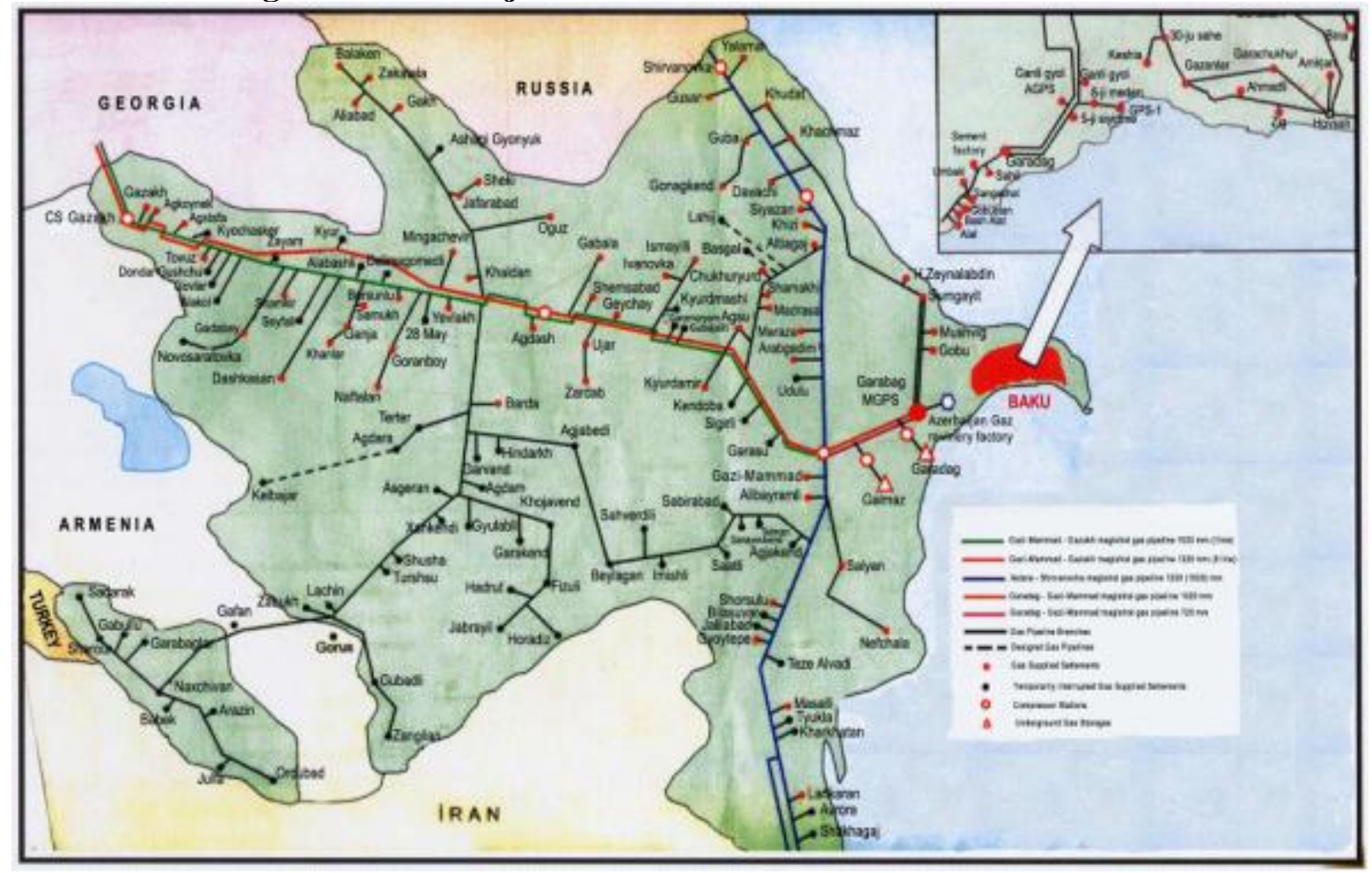

Source: Shems Energy Ltd. for World Bank

In May 2002, the Japanese Bank for International Cooperation confirmed its letter of credit for building a 90-kilometer gas pipeline from Garadag to Digyakh to the Severnaya power plant, which is under construction. Mitsui and its affiliate, Toyo Engineering, are building the pipeline and the power plant. Gas compression facilities are also being built at Garadag and Severnaya. The Frunze works at Sumsk in Ukraine are building the compression equipment. It is expected that the pipeline and compression facilities will be completed by the end of 2003.

Azerbaijan is one of the backers of the proposed Trans-Caspian Gas Pipeline, linking Turkmenbashy, Turkmenistan, to Baku via a pipeline running under the Caspian Sea. From 
Baku, the pipeline would go to Tbilisi, Georgia, and then to Erzurum in Turkey, where it would link up with the Turkish natural gas pipeline network. It is envisioned that the pipeline would be 1,700 kilometers long and carry about 16 billion cubic meters of natural gas per year. In November 1999, there was a joint declaration by Azerbaijan, Turkey, Georgia, and Turkemistan supporting the pipeline with Credit Suisse and First Boston appointed as financial advisors for the project. However, financing has not yet been found, and it is not clear whether this proposed pipeline project will proceed.

\section{Electricity}

\section{Generation and Consumption}

Electricity generation and consumption in Azerbaijan have both remained fairly flat over the past decade, in the range of about 15-19 billion kilowatt-hours (kwh) annually. Most of the generation is from thermal-electric power plants fueled by either oil or natural gas. An historical summary of electricity generation and consumption in Azerbaijan is shown in Table 8.

Table 8: Electricity Generation and Consumption in Azerbaijan, 1992-2001 (in billion kwh)

\begin{tabular}{|l|r|r|r|r|r|r|r|r|r|r|r|r|}
\hline \multicolumn{1}{|c|}{} & $\mathbf{1 9 9 2}$ & $\mathbf{1 9 9 3}$ & $\mathbf{1 9 9 4}$ & $\mathbf{1 9 9 5}$ & $\mathbf{1 9 9 6}$ & $\mathbf{1 9 9 7}$ & $\mathbf{1 9 9 8}$ & $\mathbf{1 9 9 9}$ & $\mathbf{2 0 0 0}$ & $\mathbf{2 0 0 1}$ \\
\hline Net Generation & 18.6 & 18.1 & 16.6 & 16.1 & 16.1 & 15.9 & 17.0 & 17.2 & 17.7 & 18.2 \\
hydroelectric & 1.7 & 2.4 & 1.8 & 1.5 & 1.5 & 1.7 & 1.9 & 1.5 & 1.5 & 1.9 \\
nuclear & $n / a$ & $n / a$ & $n / a$ & $n / a$ & $n / a$ & $n / a$ & $n / a$ & $n / a$ & $n / a$ & $n / a$ \\
geo/solar/wind/biomass & $n / a$ & $n / a$ & $n / a$ & $n / a$ & $n / a$ & $n / a$ & $n / a$ & $n / a$ & $n / a$ & $n / a$ \\
conventional thermal & 16.9 & 15.7 & 14.8 & 14.6 & 14.6 & 14.2 & 15.1 & 15.7 & 16.1 & 16.3 \\
\hline Net Consumption & 16.7 & 16.9 & 15.7 & 15.4 & 15.2 & 15.8 & 16.1 & 16.7 & 17.0 & 16.6 \\
\hline Imports & 0.9 & 0.3 & 0.5 & 0.9 & 0.8 & 1.6 & 0.9 & 1.6 & 0.9 & 0.4 \\
\hline Exports & 1.4 & 0.3 & 0.3 & 0.5 & 0.6 & 0.6 & 0.6 & 0.9 & 0.4 & 0.7 \\
\hline
\end{tabular}

n/a - not applicable

note: generation components may not add to total due to rounding

Source: DOE/EIA

Iran supplies approximately $60 \%$ of the electric power to the Azerbaijani enclave of Nakhchivan. Because of deliquent payments, Iran cut off deliveries from October 2000 to February 2001 and did not resume them until Azerbaijan paid its first installment on the \$45 million debt for past deliveries. Azerbaijan also has a multi-million dollar debt to Turkey for past electric deliveries to Nakhchivan, and came to an agreement with Turkey to repay the debt by transmitting Russian and Azeri electricity back to Turkey via Georgia.

\section{Installed Capacity}

There has also been a relatively flat trend for Azerbaijan's installed electricity generating capacity, with slight increases in hydroelectric capacity offset by decreases in thermal-electric capacity. An historical summary of installed electricity generating capacity in Azerbaijan is shown in Table 9. 
Table 9: Installed Electricity Generation Capacity in Azerbaijan, 1992-2001 (in GWe)

\begin{tabular}{|l|c|c|c|c|c|c|c|c|c|c|c||}
\hline & 1992 & 1993 & 1994 & 1995 & 1996 & 1997 & 1998 & 1999 & 2000 & 2001 \\
\hline Hydroelectric & 0.77 & 0.77 & 0.77 & 0.78 & 0.70 & 0.69 & 0.68 & 0.79 & 0.95 & 0.95 \\
\hline Nuclear & n/a & n/a & n/a & n/a & n/a & n/a & n/a & n/a & n/a & n/a \\
\hline $\begin{array}{l}\text { Geothermal/Solar/ } \\
\text { Wind/Biomass }\end{array}$ & n/a & n/a & n/a & n/a & n/a & n/a & n/a & n/a & n/a & n/a \\
\hline Conventional Thermal & 4.40 & 4.40 & 4.41 & 4.46 & 4.46 & 3.91 & 3.91 & 3.88 & 3.84 & 4.19 \\
\hline Total Capacity & $\mathbf{5 . 1 7}$ & $\mathbf{5 . 1 7}$ & $\mathbf{5 . 1 8}$ & $\mathbf{5 . 2 4}$ & $\mathbf{5 . 1 5}$ & $\mathbf{4 . 6 0}$ & $\mathbf{4 . 5 9}$ & $\mathbf{4 . 6 7}$ & $\mathbf{4 . 7 9}$ & $\mathbf{5 . 1 4}$ \\
\hline
\end{tabular}

\author{
n/a - not applicable \\ note: $1 \mathrm{GWe}=1,000 \mathrm{MWe}$; components may not add to total due to rounding \\ Source: DOE/EIA
}

\title{
Industry Overview
}

The state-owned company Azerenergy has a monopoly on power generation in Azerbaijan, as it owns all of the power plants. In general, most thermal-electric power plants in Azerbaijan are relatively old and in need of modernization. The largest of these is the Azerbaijan State Regional Power Plant, which was built in the 1980s and consists of eight 300 MWe units, though actual capacity is significantly lower. If funding can be found, intentions are to build two additional 300 MWe units at this facility. The second-largest thermal-electric power plant, the AliBayramly State Regional Power Plant, also has had its electricity generating capacity significantly derated; like the Azerbaijan facility, much of its equipment is in deteriorated condition. Azerenergy would like to replace the obsolete and deteriorated equipment at AliBayramly with three new 400 MWe units, but again, this will depend on obtaining the funding to do so. A new \$200 million 400 MWe natural gas-fueled expansion was completed in early 2003 to the Severnaya State Regional Power Plant (also known as the Shimal Power Plant) and is now in operation. A new gas pipeline from Garadag to the power plant is being planned.

Several of Azerbaijan's thermal-electric power plants also cogenerate steam for industrial use. All except the Baku-1 power plant are in desperate need of refurbishment. The two Baku cogeneration facilities provide steam for the two oil refineries; only the steam generator is presently being operated at the Baku- 1 facility (i.e., the entire output of the plant is used for steam production at the expense of power production), while the Baku-2 facility is in such decrepit condition that it now produces only a minimal amount of steam and power. The two cogeneration facilities in Sumgayit are in only somewhat better condition than those at Baku; there is a proposal to repower the Sumgayit- 1 facility into a combined cycle power plant that could eventually become as much as 500 MWe in capacity, but initial upgrades to the power plant will most likely include only a new steam generator and a 170 MWe steam turbine, if $\$ 150$ million in external financing/investment can be obtained. 


\section{Environmental Activities}

Azerbaijan's environmental-related activities are under the jurisdiction of the State Committee for Ecology and Use of Natural Resources. Many environmental problems exist in Azerbaijan, including severe problems of air, water, and soil pollution in the Abseron Peninsula, including the cities of Baku and Sumgayit. There appears to have been little emphasis in the past few years on assessing the environmental situation or monitoring emissions, however.

\section{Greenhouse Gas Emissions}

Azerbaijan's carbon dioxide (CO2) emissions over the past decade have been on the decline, mostly because of the country's economic problems. Decreases occurred for $\mathrm{CO} 2$ emissions from both petroleum and natural gas usage. An historical summary of $\mathrm{CO} 2$ emissions from fossil fuel use in Azerbaijan is shown in Table 10.

Table 10: Fossil Fuel-related Carbon Dioxide Emissions in Azerbaijan, 1992-2001 (in millions of metric tons of carbon)

\begin{tabular}{|l|c|c|c|c|c|c|c|c|c|c|c|}
\hline Component & $\mathbf{1 9 9 2}$ & $\mathbf{1 9 9 3}$ & $\mathbf{1 9 9 4}$ & $\mathbf{1 9 9 5}$ & $\mathbf{1 9 9 6}$ & $\mathbf{1 9 9 7}$ & $\mathbf{1 9 9 8}$ & $\mathbf{1 9 9 9}$ & $\mathbf{2 0 0 0}$ & $\mathbf{2 0 0 1}$ \\
\hline CO2 from coal & 0.02 & 0.00 & 0.00 & 0.00 & 0.00 & 0.00 & 0.00 & 0.00 & 0.00 & 0.00 \\
\hline CO2 from natural gas & 8.37 & 5.86 & 5.00 & 4.79 & 4.95 & 4.88 & 6.53 & 6.72 & 6.44 & 3.58 \\
\hline CO2 from petroleum & 7.99 & 8.00 & 7.63 & 7.45 & 5.58 & 5.53 & 6.39 & 6.10 & 5.43 & 5.56 \\
\hline $\begin{array}{l}\text { Total CO2 from } \\
\text { all fossil fuels }\end{array}$ & $\mathbf{1 6 . 3 8}$ & $\mathbf{1 3 . 8 6}$ & $\mathbf{1 2 . 6 4}$ & $\mathbf{1 2 . 2 4}$ & $\mathbf{1 0 . 5 3}$ & $\mathbf{1 0 . 4 1}$ & $\mathbf{1 2 . 9 1}$ & $\mathbf{1 2 . 8 2}$ & $\mathbf{1 1 . 8 7}$ & $\mathbf{9 . 1 4}$ \\
\hline
\end{tabular}

note: components may not add to total due to rounding

Source: DOE/EIA

\section{Privatization Status}

Privatization programs in Azerbaijan's energy sector have made some progress under the fiveyear program that has been set up in 1996 under a presidential decree. Under this decree, the state electric company Azerenergy was converted to a closed joint stock company, with the intention of privatization after its outstanding debts are paid to the state budget. However, the privatization failed in 2000, when bids were received on only 4 of the 16 distribution networks. Azerbaijan then decided to divide the national grid into five zones and form joint stock companies at these regional grids. Four of these regional distributors have since been transferred, via long-term concession agreements, to private sector companies as described previously. For the time being, at least, the intention seems to be that all significant-size electricity generating plants will remain state-owned, though, as noted earlier, some of the smallest hydroelectric power plants have been offered for privatization 


\section{Economic Situation}

In April 2001, a major restructuring of the Azerbaijan government abolished the State Property Ministry, the Economy Ministry, the Trade Ministry, the State Committee for Antimonopoly Policy and Assistance to Entrepreneurship, and the Foreign Investment Agency of the Azerbaijani Republic with their cumulative functions merged under the newly-established Ministry for Economic Development.

An historical summary of Azerbaijan's macroeconomic indicators is shown in Table 11.

Table 11: Azerbaijan's Macroeconomic Indicators, 1993-2002

\begin{tabular}{|l|l|l|l|l|l|l|l|l|l|l|l|l|}
\hline Component & 1993 & 1994 & 1995 & 1996 & 1997 & 1998 & 1999 & 2000 & 2001 & 2002 \\
\hline $\begin{array}{l}\text { Annual GDP Growth } \\
\text { Rate* } \\
\text { percent) }\end{array}$ & -23.1 & -19.7 & -11.8 & 1.3 & 5.8 & 10.0 & 7.4 & 11.2 & 9.9 & 10.6 \\
\hline $\begin{array}{l}\text { Average Inflation** } \\
\text { (percent) }\end{array}$ & 1,129 & 1,664 & 412 & 19.7 & 3.5 & -0.8 & -8.5 & 1.1 & 1.5 & 2.8 \\
\hline $\begin{array}{l}\text { Average Exchange Rate } \\
\text { (manats/US\$) }\end{array}$ & 93 & 1,211 & 4,414 & 4,300 & 3,986 & 3,868 & 4,121 & 4,565 & 4,474 & 4,893 \\
\hline
\end{tabular}

\footnotetext{
n/a - not available

* compared to previous years

** based on changes in Consumer Price Index

Sources: EBRD; National Bank of Azerbaijan
}

\section{Trade and Investment}

Azerbaijan's exports in 2001 were estimated to be $\$ 2$ billion, about $90 \%$ of which was oil and gas. Other exports are machinery, cotton, and foodstuffs. Azerbaijan exports mostly to Italy, France, Israel, and Turkey.

Azerbaijan's imports in 2001 were $\$ 1.6$ billion. The main imports were machinery and equipment, foodstuffs, metals, and chemicals. The imports are predominantly from Russia, Turkey, the United States, Iran, and Germany. 